\title{
What is the role of beta-agonist bronchodilators in the day-to-day treatment of chronic asthma?
}

\author{
PIERRE ERNST MD MSC FRCPC \\ Respiratory Epidemiology Unit, Department of Epidemiology and Biostatistics, and \\ Department of Medicine, McGill University, Asthma Unit, Montreal General Hospital Montreal, \\ Montreal, Quebec
}

P ERNST. What is the role of beta-agonist bronchodilators in the day-to-day treatment of chronic asthma? Can Respir J 1995;2(Suppl A):32A-34A.

The reported links of asthma morbidity and mortality to the use of inhaled beta-agonist bronchodilators are reviewed. Reports from the Saskatchewan Asthma Epidemiology Project (SAEP) suggest that it is excessive use that is linked to life-threatening asthma and that pationts at highest risk can be identified by their increasing use of these medications. This is the major justification for prescribing short acting beta-agonists on an as needed basis, though there is both clinical and experimental evidence suggesting regular use of these agents may not be beneficial. New longer acting inhaled beta-agonists designed for regular use are being introduced and their exact role remains to be defined. Provisionally, they appear to be useful in patients whose asthma is not well controlled with optimal doses of inhaled corticosteroids. The use of these newer agents for the relief of acute bronchospasm is contraindicated because of their slow onset of action.

Key Words: Adverse effects, Asthmu therap): Beta-agonist hromchoclitators
Quel est le rôle des bronchodilatateurs bêtaagonistes dans le traitement quotidien de l'asthme chronique?

RESUMÉ : Les liens rapportés entre la mortalité et la morbidití de l'asthme et l'utilisation de bronchodilatateurs bêtaagonistes en inhalation sont passés en revue. Des données provenant du Saskatchewan Epidemiology Project (SAEP) laissent penser que c'est leur utilisation excessive qui est associée à l'asthme quasi mortel, et que les patients à plus haut risque peuvent être identifiés par leur utilisation accrue de ces médicaments. Ceci est la justification majeure pour prescrire des bêta-agonistes à courte durée d'action au besoin, bien que des données à la fois cliniques et expérimentales laissent penser que l'utilisation régulière de ces agents pourrait ne pas être bénéfique. De nouveaux bêta-agonistes à longue durée d'action, en inhalation, mis au point pour une utilisation régulière sont présentés; leur rôle exact reste à être défini. Provisoirement, ils apparaissent être utiles chez les patients dont l'asthme n'est pas bien maîtrisé par des doses optimales de corticostéroïdes en inhalation. L'utilisation de ces nouveaux agents pour le soulagement d'un bronchospasme aigu est contriindiquée à cause de leur délai d’action prolongé.
$\mathrm{T}$ HE MEDICAL PROFESSION IHAS EMBRACED WITH GREAT confidence the selective heta2-agonist bronchodilators such as salbutamol, fenoterol and terbutaline for the treatment of bronchospasm. These agents have gradually replaced thcophyllines as first line therapy not only for acute attacks of asthma where their preponderant role remains undisputed, but also in the regular treatment of the stable asthmatic (1). In this latter role, they have been used most frequently on al continuous basis, ie, three to four times a day in order to maintain bronchodiation throughout the day and night. The short duration of action of beta-agonist bronchodilators was seen ats a drawback that limited the efficacy for the treatment

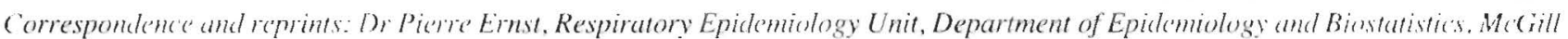
University, 1110 Pine Avenue West. Montrcal, Quebec H3A I1.3. Tel'phone (514) 398-6974, Fax (5It) 398-8981,

e-muilcrnst@makins.lun.mo:nill.cu 
of nighttime symptoms and was responsible for reduced compliance on the part of many patients. For this reason, various pharmaceutical companies undertook programs to develop long acting beta-agonist bronchodilators. Two of these, salmeterol and formoterol, were recently introduced into the European market, and salmeterol is now avillable in Canadia.

An epidenic of asthma deaths among young people in Great Britain in the mid-1960s first raised the possibility that overuse of inhaled beta-agonist medication could be hazardous (2). Several agents in use at that time were nonsclective beta-agonists such as isoprenaline. The concern regarding their overuse contributed to the development of beta2 selective agents that had fewer cardiac side cffects given the predominance of betas receptors in the heart. Much later, alarm concerning the safety of the betaz selective agents was set of by a study published by Crane and colleagues in 1989 (3), which described an association between the use of fenoterol, onc of the commonly used selective beta2-agonists, and increased risk of death from asthma in New Zealand which, at the time, had onc of the highest death rates anywhere in the world. The study design did not permit conclusions to be drawn about olher beta-agonists in common usc such as salbutamol. Furthermore, differences in the way the medication history was obtained in the cases and controls suggested the possibility of bias, which rendered the conclusions of this sludy controversial.

\section{SASKATCHEWAN ASTHMA EPIDEMIOLOGY PROJECT}

The Saskatchewan Asthma Epidemiology Project was undertaken in response to this controversy. This study, based on examination of linked computerized databases available in the province of Saskatchewan. demonstrated a doseresponse relationship between the use of inhaled selective betaz-agonists and the risk of fatal and near-fatal asthma (4). Since it appears obvious that patients with more severe disease are likely to use more medications and are also more likely to experience adverse outcomes, the cases of fatal and near-fatal asthma from Saskatchewan were matched to controls with a similar history of prior hospitalization for asthma (previously shown to be one of the most important risk fictors for fatal and near-fatal asthma) as well as the presence of other diseases that might alfect outcome. Furthermore, in a subsequent analysis, cases of fatal and near-fatal asthma were compared with the same controls after accounting for the influence of additional markers of severity obtained from hospital and office charts. The association between beta2agonists and risk of fatal and near-fatal asthma was unchanged after this additional adjustment for severity (5).

Complementary analyses of the whole cohort of over 12,000 patients suggest that the risk of major adverse outcomes is limited almost entircly to patients overusing betaagonist medications, that is, more than onc inhaler per month (6). Furthermore, it appears that the patients at highest risk can be identified by their increasing use of inhaled betaagonists over a period of several months (7). This, therefore, formally confirms clinical experience: asthmatic patients have a tendency to overuse inhaled bronchodiators because of the immediate improvement of symptoms that they experience, and this overuse worsens in parallel with their clinical state. Furthermore, this overuse of beta-agonists and other bronchodilators appears to be at the expense of the use of inhaled corticosteroids which have, in contrast to betaagonists, the capacity to improve the severity of asthma ( 8 ) and to decrease the risk of fatal and near-fatal attacks ( $(9)$.

The practice of prescribing inhaled bronchodilators to be taken on a regular basis was first seriously put into question by the report of Sears and colleagues in 1990 (I0). In a randomized, double-blind crossover study. asthmatic patients were found to be better controlled if they took their betaagonist fenoterol on an as needed basis, compared with when they were taking this medication regularly four times a day. Some of the criteria used to judge asthma control were criticized but a subsequent analysis confirmed the first impression by showing a rate of asthma exacerbations that was higher and a time to exacerbation that was shorter among those subjects taking the inhaled beta-agonist on a regular basis (11). Van Schayck (12) also reported that subjects who were taking bronchodilators on an regular basis had a greater fall in forced expiratory volume in $1 \mathrm{~s}\left(\mathrm{FEV}_{\mathrm{I}}\right)$ over a I wo-ycar period compared with subjects who were using their bronchodilator on an as needed basis only.

\section{POSSIBLE MECHANISMS}

If beta-agonists do indeed increase the risk of severe attacks of asthma, and if their regular use does bring on worsening control of asthma, what are the potential mechanisms? Tachyphylaxis to the bronchodilator effects of betaagonists does not appear to be a problem. The bronchodilator effect persists undiminished for prolonged periods (13). An increase in nonspecific bronchial hyperresponsiveness to methacholine or histamine has been found in certain studies examining the regular use of beta-agonist therapy in the treatment of asthma $(14,15)$. Such changes in bronchial responsiveness raised the possibility of a change in function of beta-agonist receptors when they are continuously stimulated. Evidence for this has been described from several sources recently. Bai and colleagues (16) described defective relaxation of smooth muscle after stimulation of the beta receptors in patients who had died of asthma. Two groups independently reported decreases in the protective effect of inhaled beta-agonists on induced bronchoconstriction by methacholine, which acts directly on smooth muscle; or by adenosine monophosphate, which acts via mast cells, among subjects who had been given either terbutaline on a regular basis or the long acting beta-agonist salmetcrol for a period of seven days and eight weeks, respectively $(17,18)$. Bel and Sterk (19) have suggested that while beta-agonists delay the onscl of bronchoconstriction in response to an agonist, the muximal degree of bronchial constriction is not decreased and the rate of bronchoconstriction may actually be increased, which could make attacks of asthma more precipitous. Page (20) has proposed that the stabilization of mast 
colls by beta-agonists might prevent a liberation of heparin and a loss of its protective effect on bronchial epithelium.

Most recently, Cockcroft et al (21) showed that among asthmatics. two weeks of treatment with salbutamol increases the degree of bronchoconstriction in response to allergen. This study is quite significant when one considers the very important role of allergy in the majority of asthmatics during childhood and young atulthood. It seems that there are several plausible mechanisms by which the use of bronchodilators on a regular basis could be responsible for a worsening asthma that might result in increased morbidity. Mitchell (22) has explained how a small increase in bronchial hyperresponsiveness in the general population could bring about al large increase in morbidity, which would be most apparent in the most severe asthmatics.

Following the epidemic of asthma deaths in the 1960s. much attention was given to the possible cardiotoxic effects of beta-agonist medications, specifically their arrhythmogenic potential. When the safety of selective beta2-agonists citme into yuestion, numcrous studies examined the relative calrdiotoxicity of the various beta2 selective agents, by using indirect measures such as tachycardia, prolongation of the Q-Tc interval on the electrocardiogram or the induction of hypokalemia (23). The importance of these phenomena in vivo, however, has yet to be demonstrated. It should be pointed out that the great majority of asthma deaths occur alfter days and sometimes wecks of gradual deterioration and that at atutopsy, the primary abnotmality is an obliteration of

ACKNOWLEDGEMENTS: Dr P Ernst is Chercheur-boursier of the Fonds de la Recherche en Santé du Québec (FRSQ)

\section{REFERENCES}

1. Kesten S, Rebuck AS, Chapman KR. Trends in asthma and chronic obstructive pulmonary disease therapy in Canada, 1985 to 1990. J Allergy Clin Immunol 1993:92:499-506.

2. Inman WHW, Adelstein AM. Rise and fall of asthma mortality in England and Wales in relation to use of pressurized aerosols. Lancet 1969;ii:279-85.

3. Crane J. Flatt A. Jackson R, el al. Prescribed fenoterol and death from asthma in New Zealand, 1981-83: case-control study. Lancet 1989:i:917-22.

4. Spizer WOS, Suissa S, Emst P, et al. The use of beta-agonists and the risk of death and near death from asthma. N Engl J Med 1992:326:501-6.

5. Emst P. Habbick B, Suissa S, et al. Is the association between inhaled beta-agonist use and life-threatening asthma because of confounding by severity? Am Rev Respir Dis 1993:148:75-9

6. Suissa S, Emst P. Boivin JF, et al. A cohort analysis of excess mortality in asthma and the use of inhaled $\beta$-agonists. Am J Respir Crit Care Med 1994:149:604-10.

7. Suissa S, Blais L., Ernst P. Patterns of increasing $\beta$-agonist use and the risk of fatal or near fatal asthma. Eur Respir J 1994:7:160)2-9.

$x$. Haahtela T, Järvinen M. Kava T, et al. Comparison of a $\beta$-2-agonist. terbutaline, with an inhaled corticosteroid, budesonide, in newly detected asthma. N Engl J Med 1991:325:388-92.

c. Enst P, Spizer WO, Suissa S, et al. Risk of fatal and near-fatal asthma in relation to inhaled corticosteroid use. JAMA 1992;268:3462-4.

10. Sears MR, Taylor DR, Print CG, et al. The use of beta-agonist treatment in bronchial asthma. Lancel 1990:336:1391-6.

I1. Taylor DR, Sears MR, Herbison GP, et al. Regular inhaled beta-agonist in asthma: effects on exacerbations and lung function. Thorax [993:48:134-8.

12. van Schayck CP, Dompeling E, van Herwaarden CLA, et al. Bronchodilator treatment in moderate asthma or chronic bronchitis: continuous or on demand? A randomized controlled study. BMJ 1991:303:1426-31.

13. Harvey TE, Tattersfield AE. Airway response to salbutamol: effect of regular salbutamol inhalations in normal, atopic and asthmatic subjects. Thorax 1992:47:280-7.

1+. Kraan J, Koeter GH, van der Mark TW, Sluiter HJ, De Vries K. Changes in bronchial hyperreactivity induced by 4 weeks of treatment with anti-asthmatic drugs in patients with allergic asthma: a comparison between budesonide and terbutaline. J Allergy Clin Immunol 1985;76:628-36. the airway lumen by thich mucus enriched with inflammatory and epithelial cells. The importance of asphyxia as it mechanism for life-threatening asthma was also underlined recently by the study of Molfino et al (24). Among patients coming to the emergency room in extremis, it was found that the predominant abnormality was respiratory acidosis and not cardiac arrhythmiat or liypokalemial.

\section{ROLE OF NEW BETA2-AGONISTS}

What is the potential role of two new long acting betiyagonists, salmeterol and formoterol, in the face of guidelines for the therapy of asthma, which now emphasize earlicr use of anti-inflammatory therapy and the use of short acting beta-agonists as rescue medication? The clinical efficacy of these new agents when used continuously as bronchodilators is clear and impressive (25) and these newer agents are often preferred by patients (26). Early evidence suggested these drugs might have significant anti-inflammatory activity (27), but they have not been shown to differ from the currently available agents such as salbutamol in this respect (28). Thus, we cannot expect these agents to have clinically significant anti-inflammatory effects. Salmeterol and formoterol will have an appropriate role to play among asthmatic patients who are inadequately controlled on optimal doses of inhaled corticosteroids in order to limit the need for oral corticosteroids and to improve the yuality of lilie of such patients. They are to be avoided, however, for the trattment of alcute attacks because of their delayed onset of action.

15. Kerrebijn KF, van Essen-Zanduliet EEM. Neijens HJ. Effects of long term treatment with inhaled corticosteroids and beta-agonists on bronchial responsiveness in children with asthma. J Allergy Clin Inmunol 1987:79:653-9

16. Bai TR, Mak TCW, Barnes PJ. A comparison of beta-adrenergic receptors and in vitro relaxant responses to isoproterenol in asthmatic airway smooth muscle. Am J Respir Cell Mol Biol 1992:6:647-51.

17. Cheung D, Timmers MC, Zwinderman AH, Bel EH, Dijkman JH, Sterk, PJ. Long-term effects of a long-acting beta-2 adrenergic receptor agonist. salmeterol, on airway hyperresponsiveness in patients with mild asthma. N Engl J Med 1992;327:1 198-203.

18. O'Connor BJ, Aikman SL, Barnes PJ. Tolerance to the non-bronchodilator effects of inhaled beta-2-agonists in asthma. N Engl J Med 1992:327:1204-8.

19. Bel EH, Zwinderman AH, Timmers MC, Dijkman, Sterk PF. The protective effect of beta-2-agonist against excessive airway narrowing in response to bronchoconstrictor stimuli in asthma and chronic obstructive lung disease. Thorax 1991;46:8-14.

2). Page CE. Hypothesis: explanation of the asthma paradox: inhibition of natural anti-inflammatory mechanisms by beta-agonists. Lancel 1991:332:712-20.

21. Cockcroft DW, McParland CP, Britlo SA, Swystun VA, Rutherford BC. Regular inhaled salbutamol and airway responsiveness to allergen. Lancel 1993:342:833-7.

22. Mitchell EA. Is current treatment increasing asthma mortality and morbidity? Thorax 1989;44:81-4

23. Wong CS, Pavord ID, Williams J, Brition JR, Tattersfield AE Bronchodilator, cardiovascular, and hypokalemic effects of fenoterol, salbutamol, and terbutaline in asthma. Lancet 1990;3367:1396-9.

2t. Molfino NA, Nannini LJ, Martelli AN, Slutsky AS. Respiratory arrest in near-fatal asthma. N Engl J Med 1991:324:285-8.

25. Pearlman DS, Chervinsky P, Laforce C, et al. A comparison of salmeterol with albuterol in the treatment of mild to moderate asthma. N Engl J Med 1992:327:1420-5

26. Ullman A. Hedner J. Svedmyr N. Inhaled salmeterol and salbutamol in asthmatic patients. Am Rev Respir Dis 1990;142:571-5.

27. Twentyman OP, Finnerty JP, Harris A. Palmer J, Holgate ST. Protection against allergen-induced asthma by salmeterol, Lancet 1990:336:1338-42.

2x. Twentyman OP, Finnerty JP, Holgate ST. The inhibitory effect of nebulized albuterol on the early and late asthmatic reactions and increase in airway responsiveness provoked by inhaled allergen in asthma. Am Rev Respir Dis $1991 ; 144: 782-7$. 


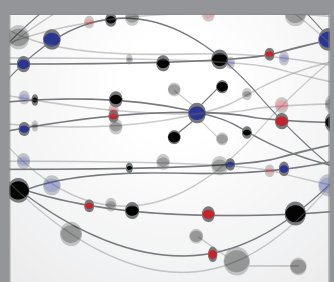

The Scientific World Journal
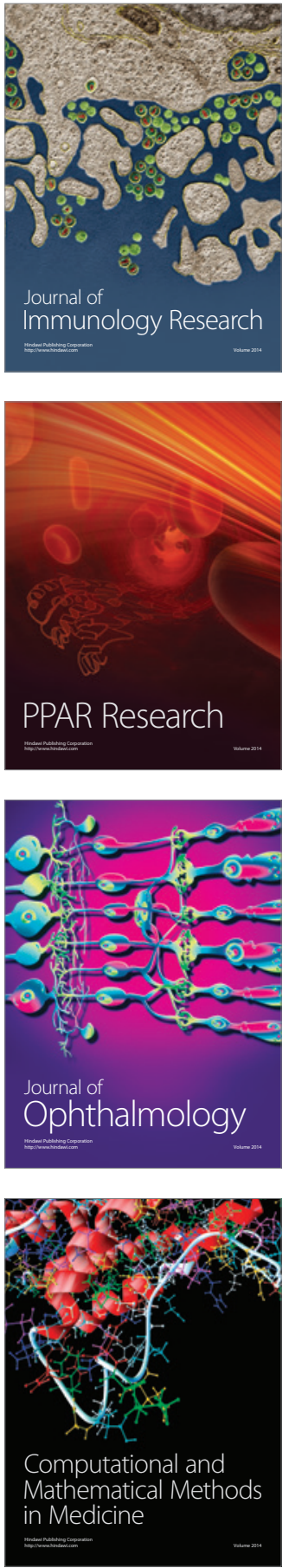

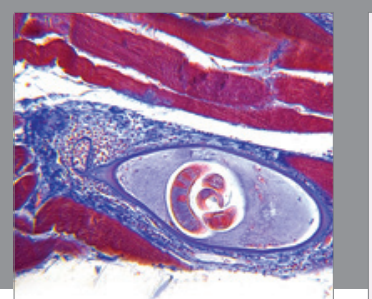

Gastroenterology Research and Practice

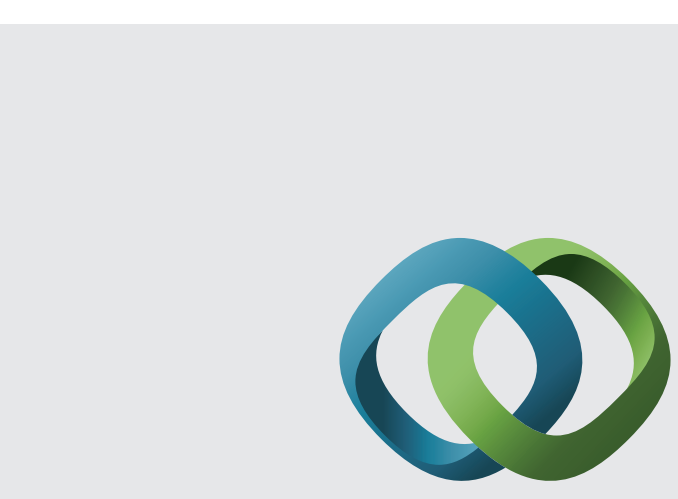

\section{Hindawi}

Submit your manuscripts at

http://www.hindawi.com
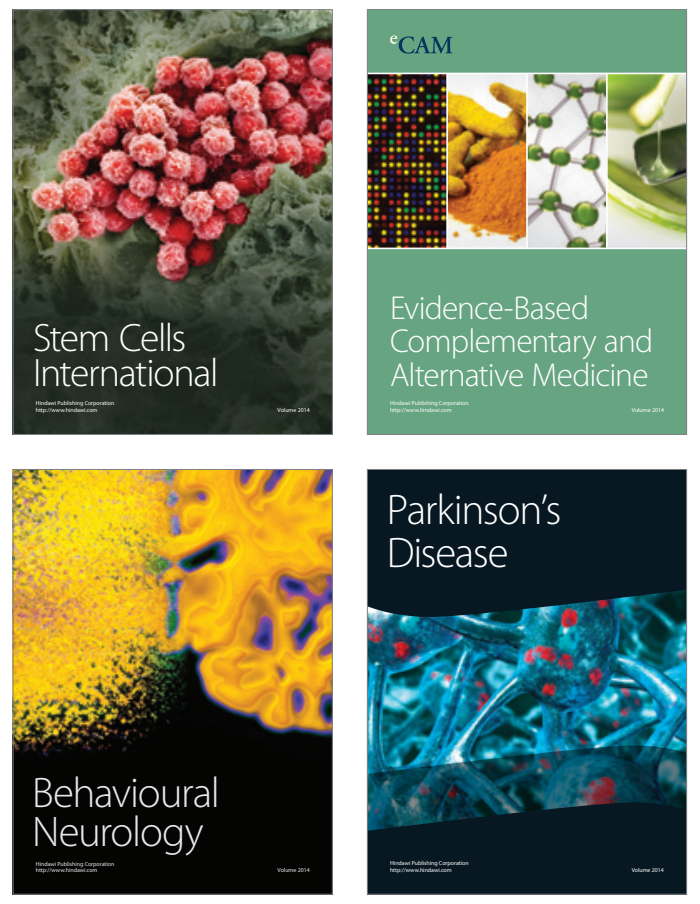
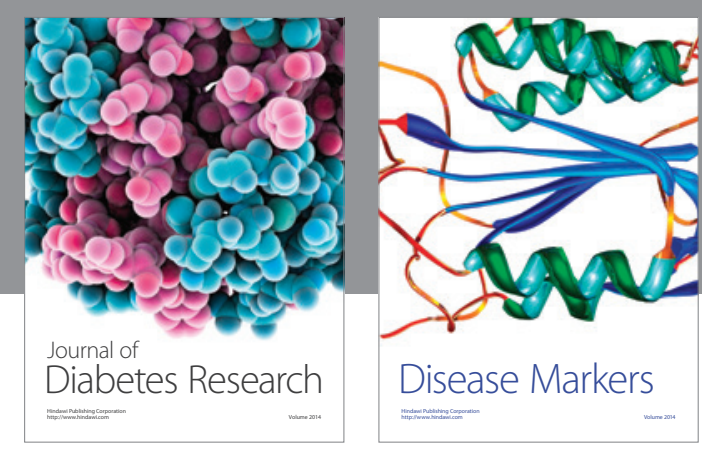

Disease Markers
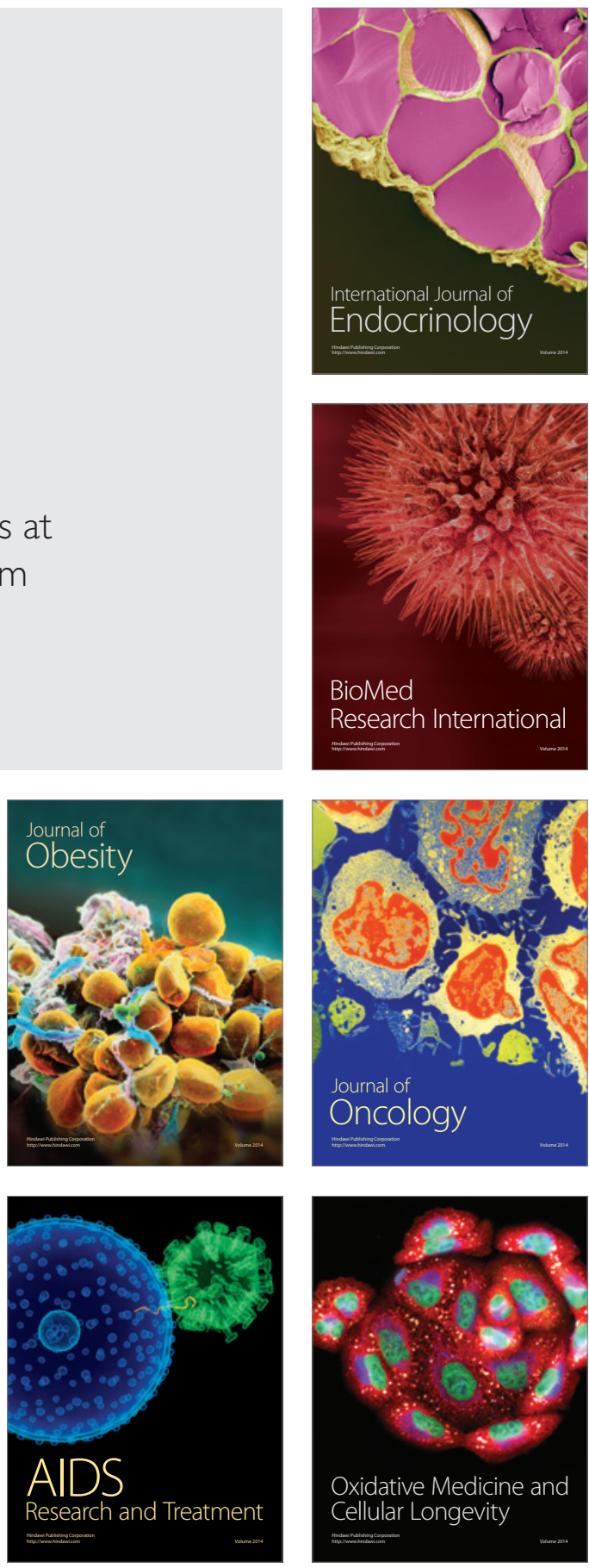